\title{
Cuticular characteristics of Neuralethopteris jongmansii LAVEINE (medullosalean foliage, Westphalian, Intrasudetic Basin, Poland)
}

\author{
Zbyněk Šimůnek \\ Czech Geological Survey, Klárov 3/131, 11821 Praha 1, Czech Republic; (zbynek.simunek@geology.cz)
}

doi: $10.4154 / g c .2017 .02$

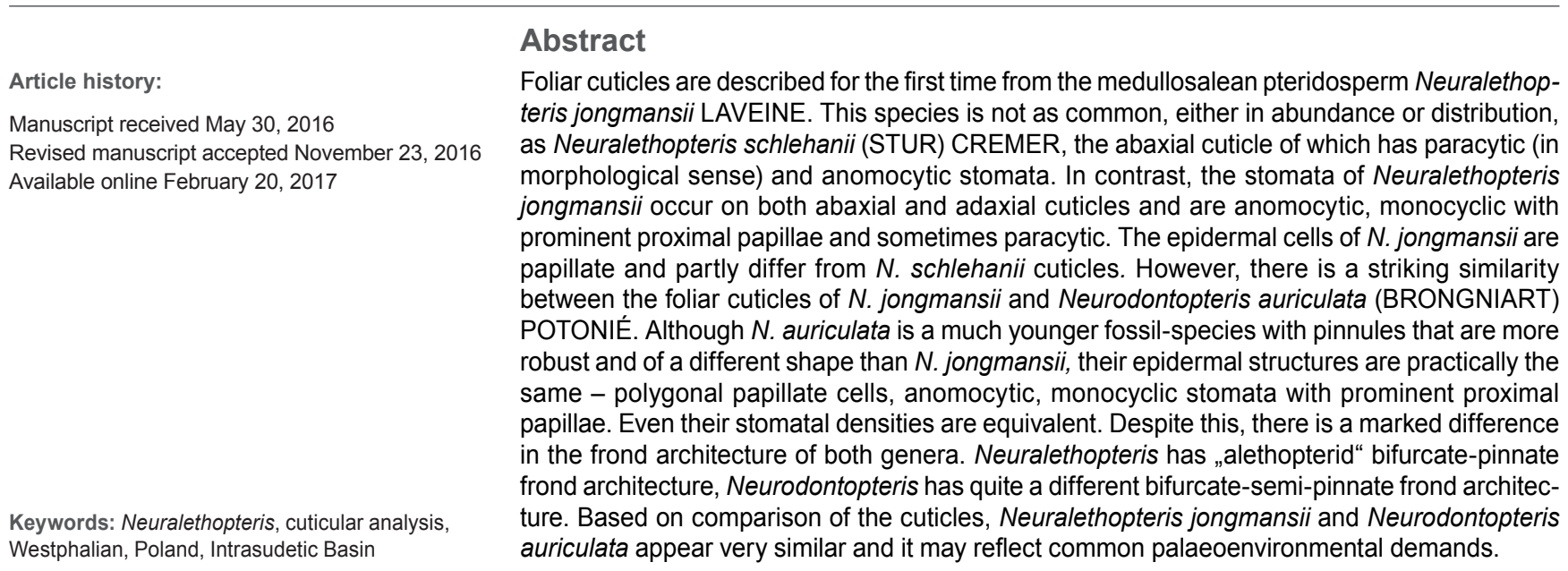

\section{INTRODUCTION}

The fossil-genus Neuralethopteris CREMER is characterised by neuropteroid pinnules that have cordate bases and alethopteroid venation (GOUBET et al., 2000). Representatives of Neuralethopteris are widespread in the Euramerican Realm, and are important biostratigraphic indicators in upper Namurian and lower Westphalian strata. Neuralethopteris schlehanii (STUR) CREMER, the type and most common species of Neuralethopteris, occurs in Euramerica, although 10 other fossil-species are known (five each from Europe and North America) (CLEAL \& SHUTE, 1995, GOUBET et al., 2000 TENCHOV \& CLEAL, 2010). To date, $N$. schlehanii is the only member of the fossil-genus for which cuticles have been studied (CLEAL \& SHUTE, 1992). During a visit to Wrocław University in Poland to study the type material of Cordaites palmaeformis (GÖPPERT) WEISS (ŠIMŮNEK, 2015), some pinnules of Neuralethopteris were found on the same slab as one of the syntypes of $C$. palmaeformis and sampled for maceration. The pinnules were identified as $\mathrm{Neu}$ ralethopteris jongmansii LAVEINE, which is relatively rare in the Intrasudetic Basin and has yet to be determined in the Czech part of the basin. In this paper, a detailed cuticular analysis is presented for $N$. jongmansii, which represents only the second species of Neuralethopteris for which cuticles are known.

\section{MATERIAL AND METHOD}

The syntype of Cordaites palmaeformis, from which the pinnules of Neuralethopteris jongmansii were collected, came from the Wałbrzych locality, Intrasudetic Basin, Poland. The syntype slab is stored in Wrocław University under no. 1667p. Although the exact horizon and stratigraphic level from which the syntype slab was collected is not known, the fact that other occurrences of $N$. jongmansii in Europe are in Langsettian (Lower Pennsylvanian) strata (CLEAL et SHUTE, 1995) suggests that it probably came from the lower part of the Žaclér Formation (Table 1).

The cuticles were prepared by a standard maceration method using Schulze's Reagent, as described by KERP (1990), KRINGS \& KERP (1997) and KERP \& KRINGS (1999).

\section{GEOLOGICAL SETTING}

The Intrasudetic Basin extends from the north-eastern Czech Republic into south-western Poland, where the Wałbrzych locality is located (Fig. 1). Mississippian strata of the Intrasudetic Basin are largely coarse-grained siliciclastics that reach $5 \mathrm{~km}$ in thickness. Sedimentation changed at the end of the Mississippian, after which the coal-bearing Wałbrzych Formation was deposited. It reaches up to $250 \mathrm{~m}$ thickness, and is of Serpukhovian and earliest Bashkirian (lower Namurian) age. The overlying coal-barren Biały Kamień Formation is up to $380 \mathrm{~m}$ thick and largely comprises sandstones and conglomerates. In the Polish part of the Intrasudetic Basin, the lower part of the overlying Žaclér Formation (upper Bashkirian, Langsettian and Duckmantian) is coalbearing. The study samples probably come from this stratigraphic level, a conclusion supported by the fact that coals of the Žaclér Formation were mined in the vicinity of Wałbrzych. The uppermost Bashkirian (Duckmantian) part of the formation only contains a few workable coal seams in the Polish part of the basin. The Moscovian and Kasimovian (upper Westphalian and lower Stephanian) Glinik Formation, which reaches $850 \mathrm{~m}$ in thickness, is practically devoid of workable coal seams. The uppermost formation in the Polish part of the basin is the Ludwikowice Forma- 
Table 1. Stratigraphy of the polish part of the Intrasudetic Basin with emphasize to the Pennsylvanian strata.

\begin{tabular}{|c|c|c|c|c|}
\hline \multicolumn{2}{|l|}{ GLOBAL SCALE } & \multicolumn{2}{|c|}{ REGIONAL SCALE } & FORMATION \\
\hline PERMIAN & Asselian & & & \multirow{2}{*}{ Ludwikowice } \\
\hline \multirow{13}{*}{ 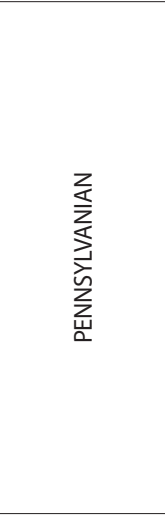 } & Gzhelian & \multirow{4}{*}{ Stephanian } & C & \\
\hline & \multirow{3}{*}{ Kasimovian } & & B & \multirow{4}{*}{ Glinik } \\
\hline & & & Barruelian & \\
\hline & & & Cantabrian & \\
\hline & \multirow{2}{*}{ Moscovian } & \multirow{4}{*}{ Westphalian } & Asturian & \\
\hline & & & Bolsovian & \multirow{3}{*}{$\begin{array}{l}\text { Žaclér } \\
\leftarrow\end{array}$} \\
\hline & \multirow{7}{*}{ Bashkirian } & & Duckmantian & \\
\hline & & & Langsettian & \\
\hline & & \multirow{7}{*}{ Namurian } & Yeadonian & \multirow{2}{*}{ Biały Kamień } \\
\hline & & & Marsdenian & \\
\hline & & & Kinderscoutian & \multirow{5}{*}{ Wałbrzych } \\
\hline & & & Alportian & \\
\hline & & & Chokierian & \\
\hline \multirow{4}{*}{ MISSISSIPPIAN } & \multirow{2}{*}{ Serpukhovian } & & Arnsbergian & \\
\hline & & & Pendleian & \\
\hline & Viséan & & & \\
\hline & Tournaisian & & & \\
\hline
\end{tabular}

$\leftarrow$ Probable location of studied sample

tion, which reaches $440 \mathrm{~m}$ thickness and largely comprises coarse-grained redbeds of Gzhelian (late Stephanian) and Asselian (early Permian) age (Table 1.) (BOSSOWSKI et al., in ZDANOWSKI \& ŻAKOWA, 1995).

\section{SYSTEMATICS}

\section{Order Medullosales CORSIN, 1960}

Family Alethopteridaceae CORSIN, 1960*

Fossil-genus Neuralethopteris CREMER, 1893 emend. LAVEINE, 1967

Type species: Neuralethopteris schlehanii (STUR, 1877) CREMER, 1893

*Family Alethopteridaceae is based on frond architecture that is an ancillary feature, however a natural botanical system should be based on fructifications. Such a family is the Trigonocarpaceae SEWARD, 1917 family, but plants with different frond architectures can have trigonocarpalean seeds. So the Alethopteridaceae family is an artificial family from this point of view.

\section{Neuralethopteris jongmansii LAVEINE, 1967}

1967 Neuralethopteris jongmansii LAVEINE: p. 107-112, pls. 2-4.

2010 Neuralethopteris jongmansii LAVEINE; TENCHOV \& CLEAL: 2010, p. 303, pls. 1, figs. 5, 6 .

Description: Two pinna fragments up to $35 \mathrm{~mm}$ long, together with several isolated pinnules are preserved on the edge of specimen $1667 \mathrm{p}$. Pinnules are small, being 5-8 mm long and usually 2-3 mm wide, and have a cordate, asymmetric base and a thick midvein that nearly extends to the pinnule apex. Lateral veins arise oblique to the midvein and arch broadly to meet the pinnule margin at $80-90^{\circ}$. Each lateral vein generally forks twice, resulting in a high vein density of $60-80$ veins per $\mathrm{cm}$ on the pinnule margin.

Adaxial cuticle: Stomata are present in the intercostal fields but absent in the costal fields. Ordinary cells are polygonal, 40-80 (100) $\mathrm{mm}$ long and 30-45 $\mathrm{mm}$ wide, and slightly elongated in the costal fields. A small papilla, up to $10 \mathrm{~mm}$ in diameter, is present in the middle of each cell. Stomatal complexes are 60-70 $\mathrm{mm}$ in diameter, and comprise two guard cells and five or six small po-

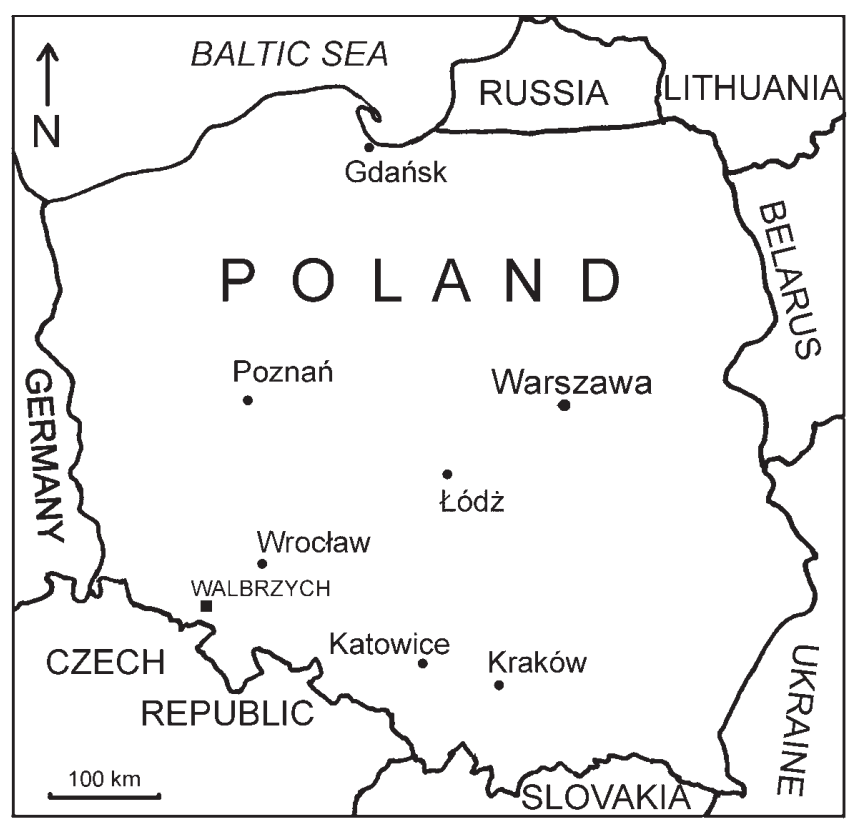

Figure 1. A map of Poland showing the locality of Wałbrzych (black square).

lygonal subsidiary cells that are $25-40 \mathrm{~mm}$ long and $15-30 \mathrm{~mm}$ wide. Cutinisation of papillae on the subsidiary cells is stronger than Cutinisation of papillae on ordinary cells. These papillae are also longer, up to $15 \mathrm{~mm}$ wide, and oriented (bent) towards the guard cells (proximal papillae). Hydathodes (Pl. I/j) are 40-45 mm in diameter and situated at the edge of pinnules. Stomatal density varies from $40-50$ stomata per $\mathrm{mm}^{2}$ and the stomatal index ranges from 8-10.

Abaxial cuticle: Abaxial cuticles are very similar to adaxial cuticles. Stomatal complexes are generally monocyclic, anomocytic, but some stomata can be also paracytic in a morphological sense (Pl. II/i). Polygonal cells are 30-80 mm long and 20-40 $\mathrm{mm}$ wide, and stomata are practically the same as those on adaxial cuticles. Stomatal density varies from $50-65$ stomata per $\mathrm{mm}^{2}$ and the stomatal index is between $8-10$, similar to the values for adaxial cuticles. Trichome bases, surrounded by six or seven ordinary cells, occur in the area that is presumed to correspond to the midvein (Pl. II/b,c,g,h). Trichome bases are circular to slightly oval and their margins are strongly cutinised. No hairs have been observed. Also occurring in these areas are stomata-like features (Pl. II/g,h), which are oval and surrounded by eight small cells, although no guard cells have been observed.

\section{COMPARISONS}

The first descriptions of cuticles of the fossil-genus Neuralethopteris were made by CLEAL \& SHUTE (1992), who noted that cuticles of the type species Neuralethopteris schlehanii have an unusual type of paracytic stomatal structure that was previously unknown in the medullosaleans. But CLEAL (pers. com. 2016) admitted that the abaxial cuticle of Neuralethopteris schlehanii was fragmentary in preservation, and some stomata can be interpreted as anomocytic, the others as paracytic. A stoma of Neuralethopteris jongmansii figured on $\mathrm{Pl}$. II/i resembles the paracytic type. Nevertheless, the cuticles of Neuralethopteris jongmansii differ from those of $N$. schlehanii (Table 2.), namely by the adaxial cuticle. In contrast to Neuralethopteris schlehanii, $N$. jongmansii also has stomata on the adaxial cuticle which represents amphistomatic foliage, a feature that, among the medullosaleans, is only known for the monotypic fossil-species Neurodontopteris 
Table 2. Important diagnostic features of the Neuralethopteris species.

\begin{tabular}{|c|c|c|c|c|c|c|}
\hline \multicolumn{4}{|c|}{ Species } & Neuralethopteris schlehanii & Neuralethopteris jongmansii & Neurodontopteris auriculata \\
\hline \multicolumn{4}{|c|}{ Authors } & TENCHOV \& CLEAL (2010) & TENCHOV \& CLEAL (2010) & ŠIMŮNEK (1999) \\
\hline \multirow{3}{*}{$\frac{\tilde{\Phi}}{\underline{\underline{E}}}$} & \multicolumn{3}{|c|}{ Length $\mathrm{x}$ width $(\mathrm{mm})$} & $(4-15) \times(2-4)$ & (up to 13$) \times(4-5)$ & $(36-42) \times(15-18)$ \\
\hline & \multicolumn{3}{|c|}{ Shape } & $\begin{array}{l}\text { Subtriangular, elongate linguaeform } \\
\text { to subfalcate }\end{array}$ & Linguaeform & Tongue-shaped with basal lobe \\
\hline & \multicolumn{3}{|c|}{ No. veins per pinnule margin } & $36-48$ & $(50-60) ;(60-80)$ & $35-40$ \\
\hline \multicolumn{4}{|c|}{ Cuticle Authors } & CLEAL \& SHUTE (1992) & This paper & KRINGS (1999); ŠIMŮNEK (1999) \\
\hline \multicolumn{4}{|c|}{ Pinnules } & Hypostomatic & Amphistomatic & Amphistomatic \\
\hline \multirow{6}{*}{ 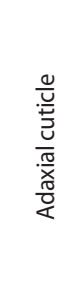 } & \multicolumn{3}{|c|}{ Costal cells } & Elongate to subrectangular & \pm Elongate, polygonal & \pm Elongate, polygonal \\
\hline & \multicolumn{3}{|c|}{ Size of costal cells ( $\mu \mathrm{m})$} & Up to $120 x$ up to 20 & {$[40-80(100)] \times(30-45)$} & Up to $100 \times$ up to 45 \\
\hline & \multicolumn{3}{|c|}{ Intercostal cells } & Irregularly polygonal & Irregularly polygonal & Irregularly polygonal \\
\hline & \multicolumn{3}{|c|}{ Size of intercostal cells ( $\mu \mathrm{m})$} & Up to $80 \times$ up to 30 & $(40-80) \times(30-45)$ & Up to 45 in the diameter \\
\hline & \multicolumn{3}{|c|}{ Form anticlinal walls } & \pm Straight & \pm Straight & \pm Straight \\
\hline & \multicolumn{3}{|c|}{ Palillae on periclinal walls } & - & + & + \\
\hline \multirow{15}{*}{ 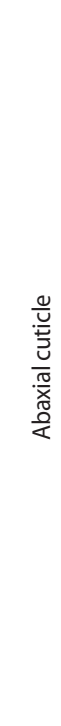 } & \multicolumn{3}{|c|}{ Costal cells } & Elongate to subrectangular & 土Elongate, polygonal & Elongate tetragonal to polygonal \\
\hline & \multicolumn{3}{|c|}{ Size of costal cells ( $\mu \mathrm{m})$} & up to $70 \times$ up to 5 & $(30-80) \times(20-40)$ & $(20-40) \times(10-15)$ \\
\hline & \multicolumn{3}{|c|}{ Intercostal cells } & ? Polygonal & Irregularly polygonal & Irregularly polygonal \\
\hline & \multicolumn{3}{|c|}{ Size of intercostal cells $(\mu \mathrm{m})$} & (up to 80 ) x (up to 20 ) & $(30-80) \times(20-40)$ & $(30-50) \times(10-25)$ \\
\hline & \multicolumn{3}{|c|}{ Form anticlinal walls } & ? Slightly bent & \pm Straight & \pm Straight \\
\hline & \multicolumn{3}{|c|}{ Palillae on periclinal walls } & - & + & + \\
\hline & \multirow{7}{*}{ 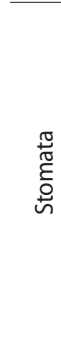 } & \multicolumn{2}{|c|}{ Distribution } & $\begin{array}{l}\text { Regularly arranged parallel to veins in } \\
\text { the intercostal field }\end{array}$ & $\begin{array}{l}\text { Mostly parallel to veins, some stomata } \\
\text { random }\end{array}$ & $\begin{array}{l}\text { a Randomly oriented in the intercostal } \\
\text { fields }\end{array}$ \\
\hline & & \multicolumn{2}{|l|}{ Type } & ?Paracytic, anomocytic; monocyclic & Anomocytic, ?Paracytic; monocyclic & Anomocytic; monocyclic \\
\hline & & \multicolumn{2}{|c|}{ Density per $1 \mathrm{~mm} 2$} & ca. 300 & $40-50 ; 50-65$ & $60-70$ \\
\hline & & \multicolumn{2}{|c|}{ Stomatal index } & 19 & $8-10$ & $?$ \\
\hline & & \multicolumn{2}{|c|}{ Shape of guard cells } & $?$ & Reniform & Reniform \\
\hline & & \multicolumn{2}{|c|}{ length and width of guard cells $(\mu \mathrm{m})$} & cca $30 \times 3$ & cca $30 \times 7$ & $(20-25) \times(4-6) ;(25-35) \times(5-10)$ \\
\hline & & \multicolumn{2}{|c|}{ Dimension of stomatal complex $(\mu \mathrm{m})$} & $?$ & $60-70$ in the diameter & $75-95$ in the diameter \\
\hline & Subs & -diary & Number and shape & 2 or more; \pm oblong (polygonal) & $\begin{array}{l}\text { 5-6; polygonal (oblong), poximal } \\
\text { papilae }\end{array}$ & 5-6; polygonal, proximal papillae \\
\hline & & & Size $(\mu \mathrm{m})$ & $?$ & $(25-40) \times(15-30)$ & $35-50$ in the diameter \\
\hline Trich & me $b$ & $\operatorname{ses}(\mathrm{sh}$ & pe and dimension in $\mu \mathrm{m}$ ) & & Circular; cca 25 in the diameter & Star-like; $40-55$ in the diameter \\
\hline Trich & mes & hape a & d dimension in $\mu \mathrm{m}$ ) & Unicellular; $120 \times 15$ & & \\
\hline Hyda & thode & (shape & and dimension in $\mu \mathrm{m}$ ) & & $\begin{array}{l}\text { Rounded on the pinnule margin; } \\
40-45 \text { in the diameter. }\end{array}$ & \\
\hline
\end{tabular}

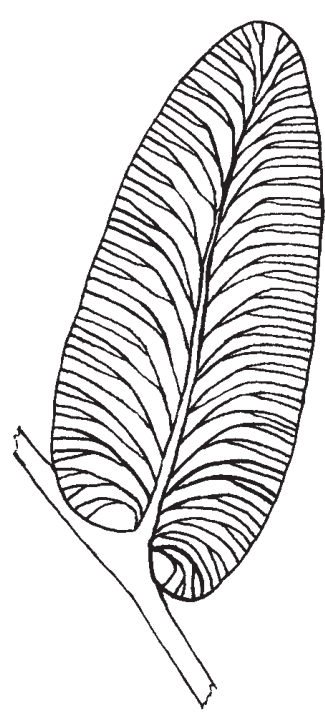

Figure 2. Venation diagram of a pinnule of Neuralethopteris jongmansii LAVEINE. Scale bar $=5 \mathrm{~mm}$. auriculata (BRONGNIART) POTONIÉ (KRINGS, 1999, ŠIMŮNEK, 1999). The cuticles of these two fossil-species are also strikingly similar.

Pinnules of Neuralethopteris jongmansii and Neuralethopteris schlehanii have comparable dimensions, but their vein densities differ, with $N$. schlehanii having 36-48 veins per $\mathrm{cm}$ on the pinnule margin and $N$. jongmansii having 50-60 (TENCHOV \& CLEAL, 2010). The studied samples had $60-80$ veins per $\mathrm{cm}$. These two species also differ in the course of the lateral veins and other features. Although $N$. schlehanii is hypostomatic and $N$. jongmansii is amphistomatic, they have anomocytic, monocyclic stomata. Some stomata can be interpreted as paracytic, as in CLEAL \& SHUTE (1992). The abaxial cuticles of both species differ in the following features: stomatal densities of ca. 300 per $\mathrm{mm}^{2}$ in $N$. schlehanii and ca. $50-65 \mathrm{~mm}^{2}$ in $N$. jongmansii, and whereas the cells of $N$. jongmansii are papillate, the cells of $N$. schlehanii are not. It is debatable whether this is the result of the poor preservation of the second species. These features can be used by distinguishing of both species. 
Even though the morphology of Neuralethopteris jongmansii and Neurodontopteris auriculata differ, their cuticles are surprisingly remarkably similar. Neuralethopteris fronds have an ,alethopterid“ bifurcate-pinnate architecture (LAVEINE et al., 1992, fig. 3). The fronds can be several metres long and do not have intercalary elements. The fronds of Neurodontopteris auriculata are about $0.5 \mathrm{~m}$ long (LANGIAUX, 1984, fig. 233) and have a bifurcate-semi-pinnate architecture. Pinnules of $N$. auriculata have a basal lobe and are much larger and wider than pinnules of $N$. jongmansii (Table 2). Furthermore, $N$. auriculata occurs in much younger strata of Stephanian B to early Permian age. Nonetheless, these two fossil-species are the only amphistomatic taxa known to date in the Order Medullosales. Both have anomocytic, monocyclic stomata, strikingly similar papillate polygonal cells, stomata with proximal papillae, and similar adaxial and abaxial cuticles. Even though occurrences of the two fossilspecies in the fossil record are separated by some $8 \mathrm{Myr}$, their stomatal densities are comparable: 50-65 stomata per $\mathrm{cm}$ for the abaxial cuticle of $N$. jongmansii and 60-70 for $N$. auriculata (Table 2.). In fact, the only distinguishing feature between the fossilspecies is the presence of star-like trichome bases (ŠIMŮNEK, 1999) in N. auriculata, although the feature only occurs on a single (?adaxial) cuticle. On the whole, distinguishing these fossiltaxa would be very difficult if only dispersed cuticles were available and the age of the strata were not known. However, both genera differ in gross-morphology. The frond architecture of Neuralethopteris is mainly based on Neuralethopteris schlehanii (LAVEINE et al., 1992), because the occurrences of Neuralethopteris jongmansii specimens are rare and fragmentary. Neurodontopteris auriculata belongs to plants with small stature (ŠIMU゚NEK, 1999). The dimensions of the Neuralethopteris jongmansii plant are not known. Due to the similarity of the cuticles with those of Neurodontopteris auriculata, it probably was also of small stature (similar palaeoecological demands of both plants) in contrast to Neuralethopteris schlehanii.

\section{PALAEOBIOLOGY}

The presence of amphistomatic pinnules in medullosaleans is exceptional. ŠIMŮNEK (1999) speculated that this feature, found in Neurodontopteris auriculata, could point to a small-statured plant, having fronds that were protected from direct sunshine.
Neuralethopteris jongmansii also had some adaptation to living in the understory (stomata on both pinnule sides). Proximal papillae on subsidiary cells around guard cells could prevent watter drops to enter the stoma opening. The adaxial and abaxial cuticles have approximately the same stomatal densities. Both species are amphistomatic and have small papillae on periclinal cell walls. This probably helped the plant to get rid of water drops from the pinnule surface. Neuralethopteris jongmansii and Neurodontopteris auriculata probably lived in similar habitats.

\section{CONCLUSION}

(1) The morphology of Neuralethopteris jongmansii pinnules is similar to those of Neuralethopteris schlehanii, The latter is the type species of the fossil-genus Neuralethopteris, although $N$. jongmansii has denser lateral veins that follow a slightly different course.

(2) The pinnules of Neuralethopteris jongmansii are amphistomatic and the pinnules of Neuralethopteris schlehanii are hypostomatic. Abaxial cuticles of both species are similar in stomatal types. $N$. jongmansii have anomocytic, monocyclic stomata, some stomata morphologically resemble the paracytic type and resemble those of $N$. schlehanii stomata.

(3) Based on cuticles, Neuralethopteris jongmansii and Neurodontopteris auriculata are strikingly similar, and are the only medullosaleans known to date with amphistomatic foliage. Both fossil-species have the same type of stomata, cell shapes and stomatal densities, indicating life in similar environments. Both plants were probably of small stature and probably lived in undergrowth.

\section{ACKNOWLEDGEMENT}

This paper was written with grant support from the Grant Agency of the Czech Republic, no. P210-12-2053. The author thanks the workers from the Collections of the Wrocław University in Poland, Dr. A. SETLIK, and Dr. P. RACZYŃSKI, for help with studying GÖPPERT's collection. The author thanks Dr. C.J. CLEAL (Cardiff) for his advice concerning neuropteroids and his critical review of the text; and Dr. A.R. BASHFORTH for English editing of the text. W.A. DIMICHELE gave as a second reviewer productive remarks that improved the manuscript.

Plate 1

Neuralethopteris jongmansii LAVEINE. loc. Wałbrzych, „Langsettian?”, coll. GÖPPERT, Wrocław Univ., Inv. No. 1667 p.

a - Pinnule margin with adaxial cuticle on the left and abaxial cuticle on the right. Slide 603/8.

b - Detail of abxial cuticle with stomata from Fig. a.

c - Close up of Fig. b with detail of stomata.

d - Adaxial cuticle on the left and abaxial cuticle on the right. Slide 602/10.

e - Detail of abaxial cuticle with stomata from Fig. d.

f - Adaxial cuticle with stomata. Slide 456/4.

g - Close up of Fig. $f$ with stomata and cells with very small papillae.

h - Close up of Fig. $f$ with details of stomata and cells of intercostal field with very small papillae.

i - Detail of s stoma from Fig. h. Note the papillae arising from subsidiary cells.

j - Margin of adaxial cuticle with hydathodes. Slide 456/5.

$\mathbf{k}$ - Close up of two hydathodes from Fig. j. 

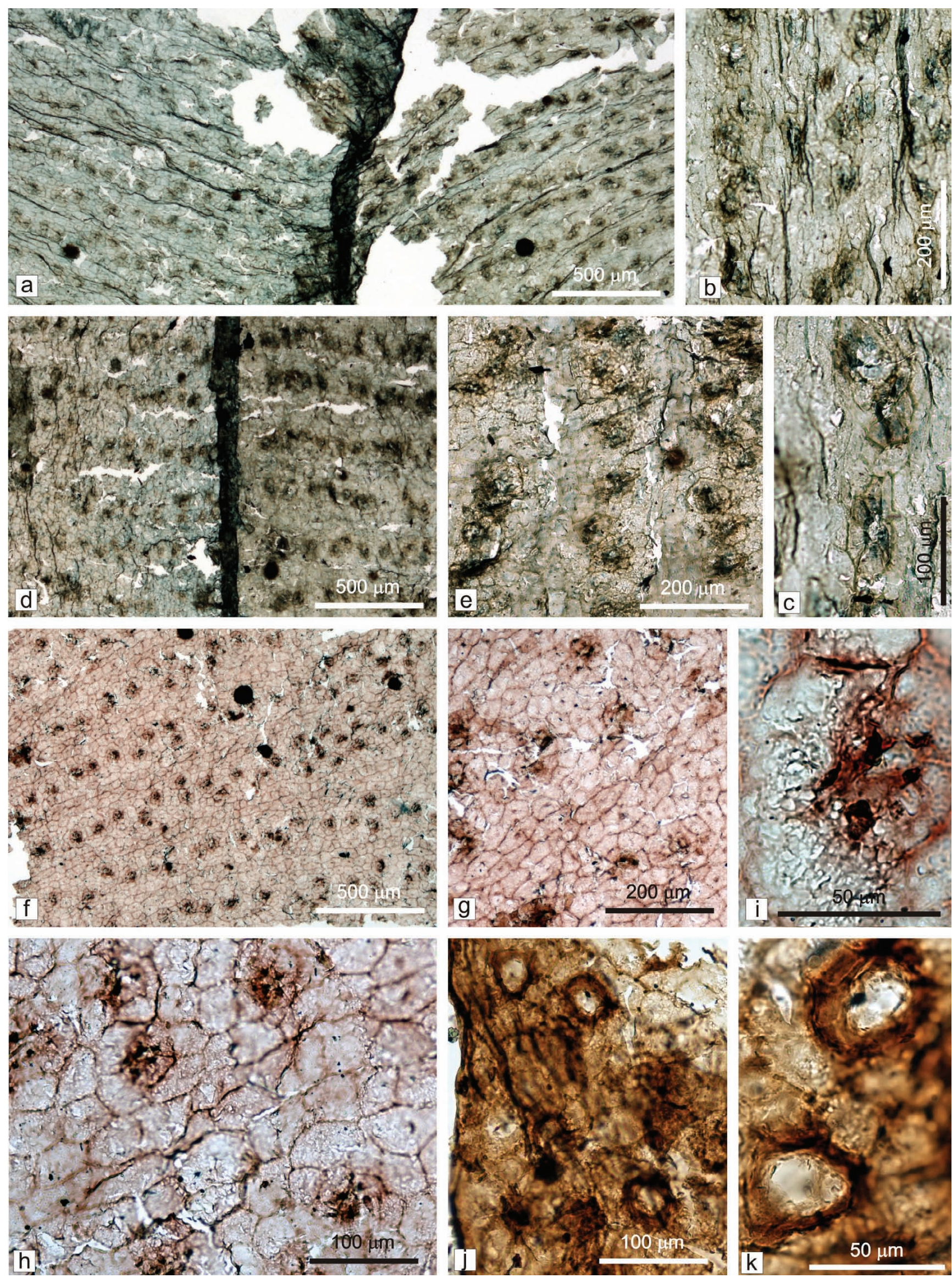


\section{REFERENCES}

BOSSOWSKI, A., IHNATOWICZ, A., MASTALERZ, K. KUROWSKI, L. NOWAK, G.J. (1995): Intra-Sudetic Depression.- In: ZDANOWSKI, A. \& ŻAKOWA, H. (eds.): The Carboniferous System in Poland. Prace Państwowego Instytutu Geologicznego, 124-146, Warszawa.

CLEAL, C.J. \& SHUTE, C.H. (1992): Epidermal features of some Carboniferous neuropteroid fronds.- Review of Palaeobotany and Palynology, 71, 191-206. doi: 10.1016/0034-6667(92)90162-A

CLEAL, C.J. \& SHUTE, C.H. (1995): A synopsis of neuropteroid foliage from the Carboniferous and Lower Permian of Europe. Bulletin of the British Museum (Natural History).- Geology Series, 51, 1-52.

CORSIN, P. (1960): Classification des Ptéridophytes et des Ptéridospermophytes du Carbonifère. Bulletin de la Société Géologique de France 2 (Série 7), 566-572.

CREMER, L. (1893): Über die Fossilen Farne des Westfälischen Carbons und ihre Bedeutung für eine Gliederung des letzeren. Mitteilungen aus dem Geologischen Museum der Westfälischen Berggewerkschaftskasse, 1, 1-49.

GOUBET, P., PFEFFERKORN, H.W. \& GILLESPIE, W.H. (2000): Neuralethopterids (trigonocarpalean pteridosperms) from the Early Pennsylvanian of eastern North America.- PaleoBios, 20, 11-37.

KERP, H. (1990): The study of fossil gymnosperms by means of cuticular analysis.Palaios, 5, 548-569. doi: 10.2307/3514861

KERP, H. \& KRINGS, M. (1999): Light microscopy of cuticles.- In: JONES, T.P. \& ROWE, N.P. (eds.): Fossil Plants and Spores: Modern Techniques. Geological Society, London, 52-56.

KRINGS, M. (1999): Zum Bau der Spaltöffnungsapparate von Neurodontopteris auriculata (Brongniart) Potonié, einer Pteridosperme aus dem Stefan von Blanzy-Montceau (Zentralfrankreich).- Münstersche Forschungen zur Geologie und Paläontologie, 86, 69-78.
KRINGS, M. \& KERP, H.(1997): An improved method for obtaining large pteridosperm cuticles.- Rev. Palaeobot. Palynol., 96, 453-456. doi: 10.1016/S00346667(96)00059-0

LANGIAUX, J. (1984): Flores et Faunes des formations supérieurs du Stéphanien de Blanzy-Montceau (Massif Central français). Stratigraphie et paléoécologie. Revue Périodique de ,La Physiophyle‘, Societé d` Études des Sciences Naturelles et Historiques de Montceau-les-Mines, 100 (Supplément), 1-270.

LAVEINE, J.-P.(1967): Contribution a l'étude de la flore du terrain houiller. Les Neuroptéridées du Nord de la France.- Études Géologiques pour l'Atlas Topographie Souterraine, 1/5, 1-344, pls A-P, 1-84.

LAVEINE, J.-P., BELHIS, A., LEMOIGNE, Y. \& ZHANG, S. (1992): Frond architecture in the genera Neuralethopteris CREMER, Alethopteris STERNBERG and Lonchopteris BRONGNIART (Carboniferous Pteridosperms).- Revue de Paléobiologie, Volume spécial, Geneva, 6, 149-166.

SEWARD, A.C. (1917): Fossil plants. Volume III. Pteridospemae, Cycadofilices, Cordaitales, Cycadophyta.- Hafner Publishing Company, New York \& London (reprint 1963), 656 p.

ŠIMU゚NEK, Z. (1999): Cuticles of Neuropteris auriculata (BRONGNIART) POTONIÉ from the Stephanian B of the Czech Republic. Acta Universitatis Carolinae.- Geologica, 43, 4, 625-631.

ŠIMŮNEK, Z. (2015): Cuticles of the Polish type material of Cordaites palmaeformis (GÖPPERT)WEISS and a Cordaites principalis-like form from Germany, Pennsylvanian.- Review of Palaeobotany and Palynology, 223, 50-70.

STUR, D. (1877): Die Culm-Flora der Ostrauer und Waldenburger Schichten.- Abhandlungen der Kaiserlich-Königlichen Geologischen Reichsanstalt, 8/2, 107-472.

TENCHOV, Y. \& CLEAL, C.J. (2010): Neuralethopteris foliage (Medullosales) in the Carboniferous of the Dobrudzha Coalfield, Bulgaria.- Review of Palaeobotany and Palynology, 158, 298-307. doi: 10.1016/j.revpalbo.2009.10.001

\section{Plate 2}

Neuralethopteris jongmansii LAVEINE. loc. Wałbrzych, „Langsettian“, coll. GÖPPERT, Wrocław Univ., Inv. No. 1667 p. Abaxial cuticles.

a - Two stomata with papillae on subsidiary cells. Slide 602/9.

b - ? probably an area of midrib with ?trichome basis. Slide $602 / 10$

c - Close up of two trichome bases from Fig. b.

d - Abaxial cuticle with stomata. Slide 603/8 (cuticle from PI. I, a).

e - Close up of two stomata from Fig. d.

f - Close up of a stomata from Fig. d. Note the papillae on subsidiary cells.

g - ? Probably midrib with trichome bases. Slide 603/9.

h - Close up of trichome bases? from Fig. $g$.

i - Close up of a stoma resembling the paracytic stomatal type. Slide 602/11.

j - Abaxial cuticle with stomata. Slide 603/7. 

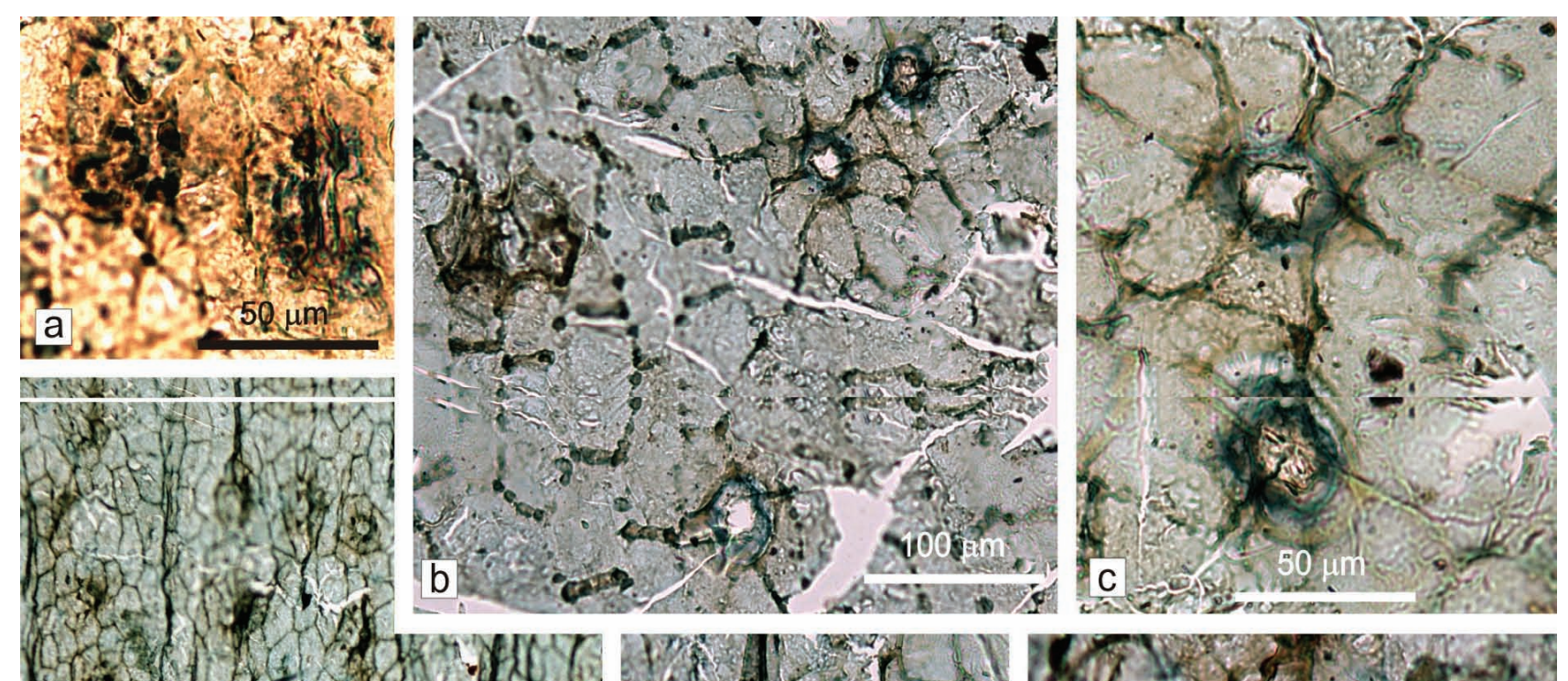

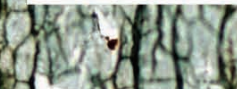

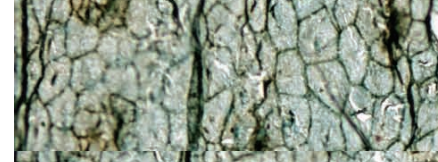

(1)
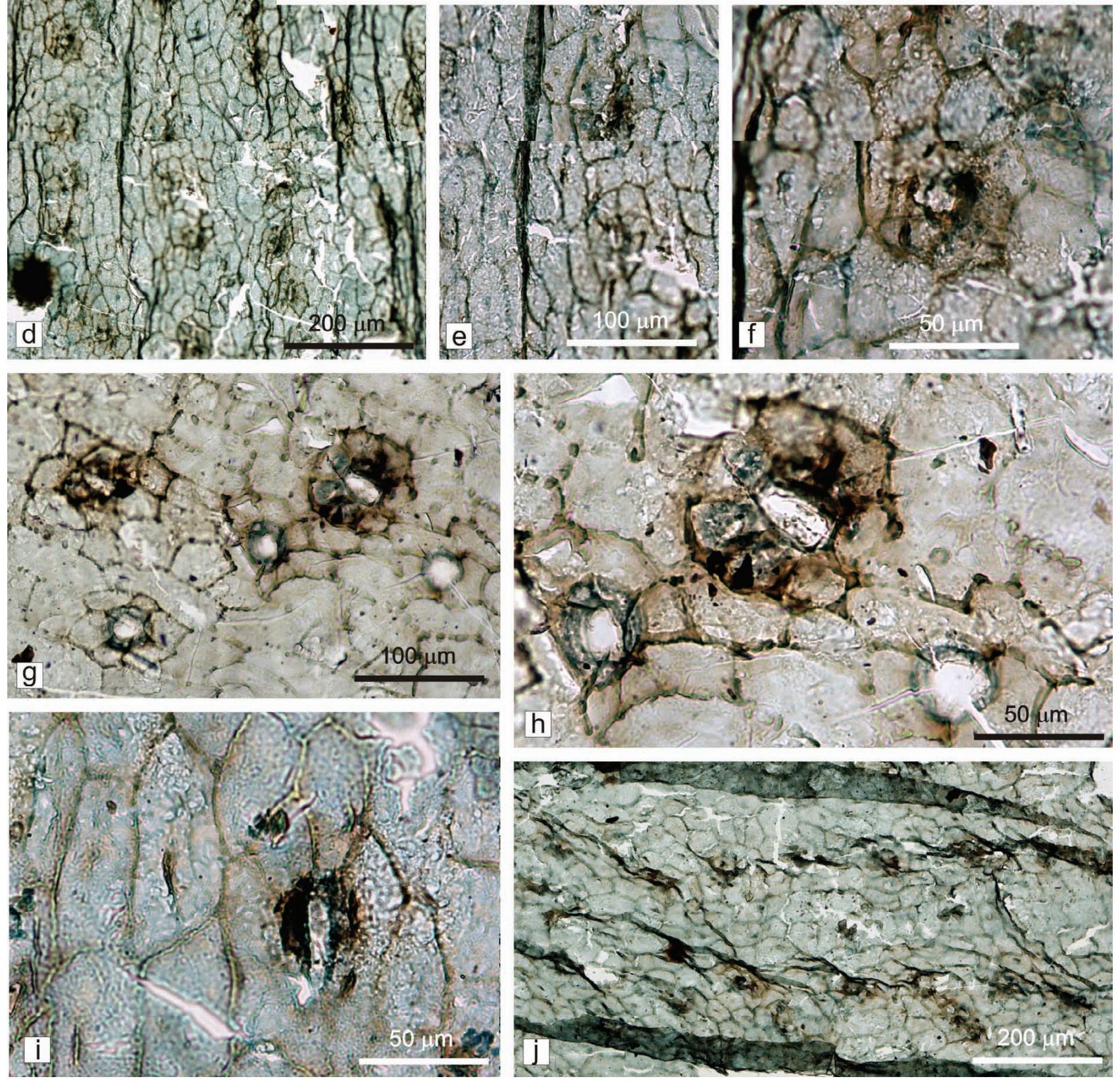


\section{Plate 3}

Neuralethopteris jongmansii LAVEINE. loc. Wałbrzych, "Langsettian”, coll. GÖPPERT, Wrocław Univ., Inv. No. 1667 p. Abaxial cuticles and cuticles in SEM.

a - Abaxial cuticle with costal and intercostal fields; intercostal fields with stomata and small papillae on epidermal cells. Slide 603/6.

b - Close up of three stomata from Fig. b. Note the papillae on the subsidiary cells and normal epidermal cells.

c - Abaxial cuticle with stomata. Slide $456 / 3$

d - Close up of abaxial cuticle with stomata and papillae on epidermal cells from Fig. c.

e - Close up of a stoma from Fig. d. Note the papillae on the subsidiary cells.

f - Cuticle under SEM. Stomata are not discernible. SEM stub 39.

g - Abaxial cuticle in SEM. SEM stub 84.

h - Close up of abaxial cuticle from Fig. $g$. 

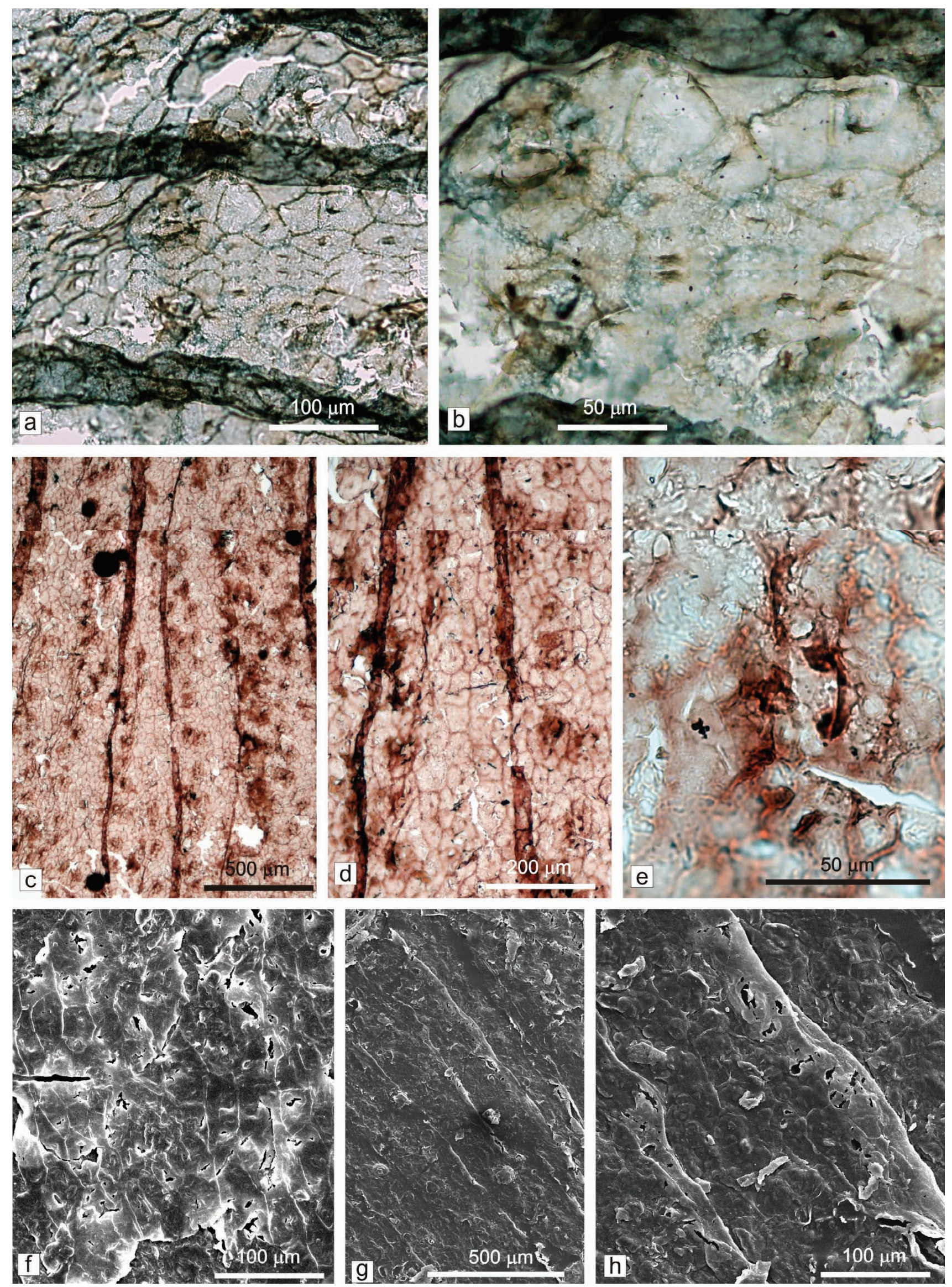

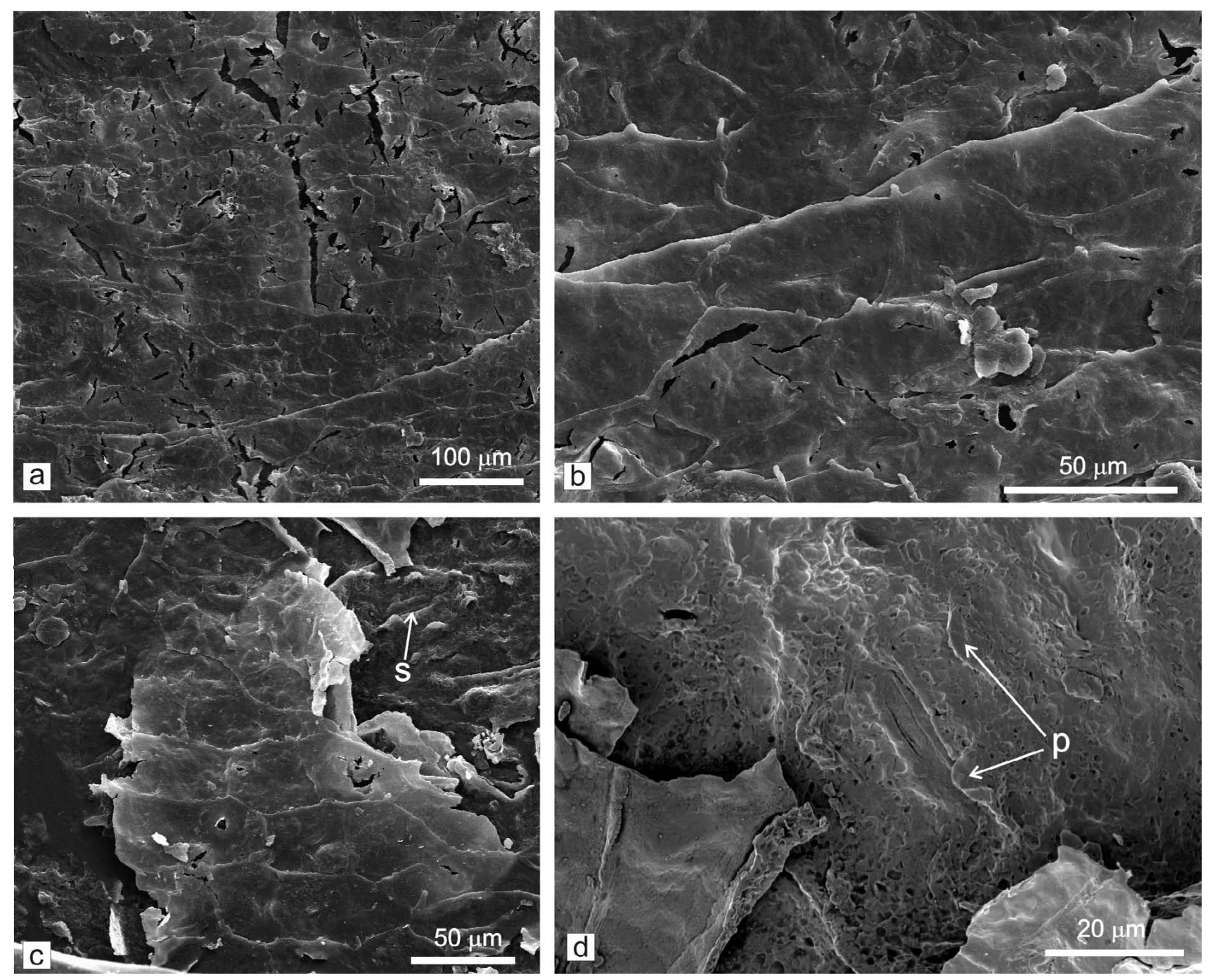

Plate 4

Neuralethopteris jongmansii LAVEINE. loc. Wałbrzych, „Langsetian“, coll. GÖPPERT, Wrocław Univ., Inv. No. 1667 p. Cuticles under SEM.

a - Cuticle in inner view with discernible anticlinal walls. SEM stub 84.

b - Detail of Fig a., with discernible anticlinal cell walls and small papilla-like projections on the corners of cells.

c - Cuticular fragment from the inner side with clearly discernible cells (lighter) and a stoma (s) on the cuticle in background in the upper right corner. SEM stub 84.

d - Detail of the stoma from Fig. c. Note the papillae (p). 